\title{
Learning content versus social environment. A comparative analysis from traditional initiation and modern high-schooling in Java (Indonesia)
}

\author{
Jean-Marc de Grave ${ }^{\text {* }}$, Puji Yanti Fauziah ${ }^{2}$ \\ ${ }^{1}$ Département d'anthropologie - Aix-Marseille Université. 29, avenue Robert Schuman \\ 13621 Aix-en-Provence Cedex o1, France \\ ${ }^{2}$ Department of Nonformal Education, Universitas Negeri Yogyakarta. \\ Jalan Colombo No. 1, Karangmalang, Yogyakarta 55281, Indonesia \\ ${ }^{*}$ Corresponding Author. Email: jmdg58@yahoo.fr
}

Received: 29 October 2019; Revised: 8 November 2019; Accepted: 11 November 2019

\begin{abstract}
The circulation of contents depends on the marked separation of social domains and subdomains: they are transformed from one domain to another (from the scientific milieu to the media or the school environment, for example). A competition of domains is thus developed, which aims to enhance the radiance of contents reflecting knowledge some of which dominate, others not, others are ignored or unrecognised and still others disappear. Finally, the description of Indonesian high schools presents modes of transmission that do not overvalue the learning content to the detriment of relationship established between the different members of some of these high schools. The two first high schools I have described (SMA3 and de Britto), present in their internal operating mode of transmission the same configuration as the nyantri system found in traditional kanuragan insofar as it shows how it is very difficult, if not impossible, to separate a so-called learning content from a learning community and a social environment. From these two examples we can understand that socialising ability is all the same educable and transmissible in a high formal context, and that the positive integration of the relation to time, space and others clearly adds that of the relation to knowledge.
\end{abstract}

Keywords: ritual initiation, high schools, social relations, apprenticeship, social values, education, Java, Indonesia

How to Cite: de Grave, J., \& Fauziah, P. (2019). Learning content versus social environment. A comparative analysis from traditional initiation and modern high-schooling in Java (Indonesia). JPPM (Jurnal Pendidikan dan Pemberdayaan Masyarakat), 6(2), 146-16o. doi:https://doi.org/10.21831/jppm.v6i2.27844

do: https://doi.org/10.21831/jppm.v6i2.27844

\section{INTRODUCTION}

An expressive image of acquiring knowledge is traditionally found in Java between a stepson and his father in law-a classificatory father-through the wedding with the daughter of the latter. This image expresses precisely the socialising dimension of learning as a consequent relational mode. This way of learning by establishing a privileged relation is locally called nyantri, that is to say to learn from a teacher and within a group, the second aspect being also very important insofar as learning is community-based. This is a powerful image of the relationship that occurs between the classificatory father and the student, from the perspective of a study of the modes of transmission. An opposite extreme image would be that of the distance learning spread in the West, in which one do not need to meet almost anyone.

In the nyantri case - a notion of ancient Hindo-Buddhist origin, taken up within the framework of local Muslim communities the relationship is rather dense, since the student is integrated into an explicit and physically present learning community: a father (the master), a mother (headmistress or wife of the master), and/or elder and/or younger brothers and sisters (in relation to apprenticeship), not counting aunts, uncles, the cogeneration of the master or the mistress, all classificatory: the apprentice is thus unlikely to be alone. 
Conversely, the self-taught distance education student is sure to find himself left alone. Thus, such a student appears to be a highly developed case of the individual action isolated from the human social context through the sporadic and discontinuous contacts he establishes with different and non-homogeneous social environments. This non-homogeneity is elaborated thanks to an increased emancipation of the learning content, conferring on this content numerous possibilities of manipulation in time and in space.

Here are two poles related to two modes of learning. They reveal two types of social relation concerning the use of knowledge, and two kinds of conceptualisation concerning the purpose of the same knowledge. In a schematic way, in the first trend, knowledge is not distinguished (or comparatively fewer) from the social environment in which it operates, whereas in the second, knowledge is isolated to a high degree from the relational context of the social space. Social ties and the cultural dimension are an integral part of the first trend, where they are reduced to their simplest device in the second one.

Between these two configurations, I worked on Javanese, Indonesian and more widely Malay transmission systems of practices and knowledge. These include apprenticeship modes of Javanese ritual initiation, Indonesian and Malaysian martial arts schools, Javanese dance and, more recently, Indonesian koranic schools and Indonesian high-schools. The studies connected with this research make it possible to envisage the two poles I have just mentioned in terms of formalisation/non-formalisation of knowledge and apprenticeship modes. Through the analytical results obtained on the basis of these studies, I propose here to develop the outline of a more general reflection on the status of knowledge in relation to the notion of "content".

In the first part of the paper, I will focus on the relation between the relative hermeticity of social domains and some apprenticeship systems characterised by a form of sociability that denies an integral dimension of space, time and others. I will illustrate this denying with the example of how evolved the Javanese ritual initiation in the contemporary socio-political and religious networks. This case study will show us how a given social practice (initiation) - and its corpus of knowledge and know-how - is integrated to social areas in the course of increasing more and more autonomy with respect to one another.

This will lead me to develop the analysis in the following section by presenting different transmission modi operandi of this ritual initiation, but also those of Indonesian high schools. I propose in particular a criticism of the "practice-theory" approach in favor of a knowledge-based approach not focused on contents (of knowledge) as ultimate element of the transmission process. Rather, the contents I mean are including in a significant way the social anchoring of their constitution, circulation and transmission.

Therefore, the results of the analysis are to be understood in a comparison of the studied systems and not in terms of absolute value (De Coppet, 1992; Dumont, 2015). Considering the manipulability of contents as introducing a gap between knowledge and social anchoring, allows us to better understand how they position each other within social logics. This, in turn, must contribute to the necessary distance from utilitarian approaches to school-based education and, more generally, to knowledge, whether formal or informal.

\section{RESULT AND DISCUSSION}

\section{Relational Competition Between Different Social Fields}

Between the two extremes of transmission systems located in a well-defined learning community and transmission systems developed in a very impersonal environment, we find standardised systemsincluding the formal school system-and their possible contradictions. Contradiction and malfunctioning are often sought in contents (apprenticeship and learning), in the organisation of these contents (programs), or in the inadaptability within a broader social framework. In my opinion, the answer to these questions lies more in a better recognition of 


\section{JPPM (Jurnal Pendidikan dan Pemberdayaan Masyarakat), 6 (2), 2019 - 148}

Jean-Marc de Grave, Puji Yanti Fauziah

the close interplay between the educational system and the social model of reference.

Durkheim, by criticising Kant and the advocates of an ideal education, points this aspect to the finger: "They [the definitions concerning education] start from this postulate that there is an ideal, perfect education, which applies to all men indiscriminately, and it is this universal and unique education which the theorist endeavors to define [...]. What can be useful to imagine an education that would be fatal to the society that would put it into practice?" (Durkheim, 1980, p. 43). His reasoning, of course, includes the link between education and all existing social institutions and practices without which "an educational system has nothing real by itself" (Durkheim, 1980, p. 43).

But in this explanation of the educational system conformation as dependent on its integration with the encompassing fields of "religion, political organisation, the degree of development of the sciences, the state of industry, and so on" Durkheim seems to omit - at least in part - the influence in return of this system on these domains. In addition to this influence, one must also speak of the persistence of this system through the immediately visible external changes that concern it.

The examples I have worked on illustrate very well these round trips with the process of formalisation of the Javanese ritual initiation (and more widely Indonesian and Malay ones) which takes the form of martial arts schools (de Grave, 2001). In particular, it is the systematic resumption of this widely practiced activity by the various religious tendencies of the archipelago - not only by the traditionalist Islam of the Koranic schools, which in all probability inherited it from the previous Hindo-Buddhist period, but also of reformed Islam and Catholicism. The very popular nature of this activity until the late 1990s, stands in the fact that it is basically rooted in local cosmological and value systems, but also adapted to modernity, notably through sport conceptions. Formal political networks, for reasons of police security but also and above all for reasons of notoriety, have in fact always been attached to the traditional and modern groups and networks of these martial arts glossed today under the generic term of pencak silat (during the pre-independence period of the 1940s, the independence war period of the 1945-1948, then the post-independence of 1950 to 1998 , and till today).

The same goes for economic networks, with the organisation of courses for employees of companies and offices, and the sponsorship of related sports or cultural events. Similarly, the military, police, public or private services employ instructors, and important political or religious groups have their own schools or security services, both of which often overlap. Thus, in the 20oos, we witnessed the confrontation of high-level politicians to fight bitterly over the leadership of the national federation of pencak silat (de Grave, 2013). One of them, Prabowo Subianto, who actually became leader of this federation in 2003, was the main competitor of the current president - Joko Widodo - in the 2014 and the 2019 elections.

Through my research, I have been able to show how the transmission systems of these groups were constructed in a concomitant way with the progress of the school practices, the organisational mode of the Japanese martial arts schools, and the sports circles. In these transmission systems, we can clearly find borrowings from the school context (importance of writing and formal curriculum, practice of examination and valuation of formal results, clear cut between teachers and students, conceptual separation of bodily activities from mental or emotional activities) and vice versa (marked presence of these martial arts in schools, influence on other bodily practices, influence of the social ethics they usually convey).

If we define initiation as a ritualised passage for the accession to adult status - a passage which enshrines the incorporation of practices and knowledge considered important within the referent group - the concerned initiatory mode must deal with the (quasi)whole entirety young people of the group. From this point of view, school, and in particular high school which sees the latter becoming adults, has become for Indonesia, and for the regions which constitute it, what ritual initiation has been to the Javanese and 


\section{JPPM (Jurnal Pendidikan dan Pemberdayaan Masyarakat), 6 (2), 2019 - 149}

Jean-Marc de Grave, Puji Yanti Fauziah

other groups at some point in their history. In the process of the combined learnings of the cosmological environment considered important by the Javanese for their children, and of elements relied to urbanisation, political and economical constraints, it is often difficult to say which set of ultimate social values is the most important in the eyes of its respective members at a given $t$ time.

Thus, returning to this idea of movement going back and forth between practices linked to learning systems and the constitution of social domains, an increased effort is needed to show precisely where and how one given system of transmission (perpetrated at school, or amongst martial arts or dance groups, or any type of learning context) produces one given social model, and where and how this social model directs or attempts to absorb this system, which implies to pay attention on ethical issues which are put in practice in the process.

Keeping these questions in mind, I will rely here on one of the contradictions I have described through various cases of school study (Grave, 2012): social relationships (not to be confused with politeness or respect for values) are paradoxically unlearned in formal school-type training systems, unlearned as a norm of sociability before relearning them by experience, ie behaving with the others while knowing how to keep one's distance as it was integrated at school. ${ }^{1}$

We also learn at school the almost universal validity of the knowledge taught (supposed to be rather immutable), before unlearning it in higher education where one must become familiar with this new idea (for the students) that the Sciences - when not transposed to facilitate understanding - are in perpetual conceptual movement (Pierrot, 2012; Rorty, 1989). This new understanding frequently represents a real internal revolution for beginner students who have to adapt to a new way of understanding knowledge.

These paradoxes did not happen at once. They are linked in particular to the

1 The isolation of the student in the midst of his/her classmates facing the teacher's authority is overvalorisation of the content of knowledge in relation to the dominant social values. In the dialogue between practices and values, the latter are gradually reoriented to the point of giving place to other values corresponding to other practices (ritual, religious, martial, scientific, managerial ...). Little by little, practices and values change, certain attributes are transmitted from one domain to another, others are relegated to the background or disappear (Dumont, 1977, 2015).

In the process of school transmission, certain practices are not recognised as such because they concern us too closely for us to distinguish them. This is so for relational exchange and, with it, the modes of learning which seem to us to be the most natural thing in the world, but which vary markedly from one region to another, from one continent to another, not forgetting from one period to another. We can easily see this difference from one generation to the next: techniques and the relation to knowledge change, the next generation often seems less skilled for the one preceding it, blind to the implicit changes that intervene gradually over time, blind to the general social background of the past.

More specifically, what happens when, through school practice (combined with that of parents' professional obligations), the relationship of the student with his family, neighborhood, regional culture or language, is disjoined? A tension of unlearning-relearning, such as that noted above, certainly. But what happens when the content becomes more and more abstract from the empirical social and environmental data (in the simple sense of immediate physical and social environment) and in a quasi-systematic way? What happens to the look one throws to one's family over the two or three hours a day that we spend, at best, with them?

In relation to this process in which people are taken in separated logics - family, school, work, leisure ... - there has probably not been a golden age of social relationship, but different cases which place the respective

the most striking aspect of this unlearninglearning process. 


\section{JPPM (Jurnal Pendidikan dan Pemberdayaan Masyarakat), 6 (2), 2019 - 150}

Jean-Marc de Grave, Puji Yanti Fauziah

relationship modes at different levels corresponding to different logics. The question is whether there exist contexts conducive to enact a qualitative way of social relationship. Such a way could be objectively identified notably through conceptions to space and time as non-ideologically marked elements.

In this way, by comparing different apprenticeship systems, something primordial appears at the level of the interstice: learning (at school) by privileging the relational aspect (qualitative human)/learning by privileging the learning content (republican secular egalitarianism with marked normative tendencies). Emphasising the content expresses two potentially positive elements: egalitarianism of opportunity, avoidance of abuse (favoritism, fraud, harassment ...). But the concomitant side or perverse effects are not taken into consideration. Thus, to the egalitarianism of the chances correspond anonymity, the shift towards a form of elitism to the detriment of those for whom the system is not adapted, and the non-reducible part of subjectivism of the evaluators. The avoidance of abuses corresponds to the rigidity of relations, the decontextualisation of relationship and the abstraction of the knowledge to be transmitted (Goody, 2007; Goody \& Paulme, 1994).

Within this general framework, one can wonder about the negative socialising dimension caused by the impact of passivity and worse - of failure at school: what happens to human relations and ease of oral expression developed outside class? What consequences do the mental block in class have on the overall life of the student? What influence do they exert on the knowledge which they have incorporated and learned by themselves? About this strong influence (Dumazedier, 1988) shows that recreational, associative or leisure activities outside school are more formative than school activities to develop the capacities of decision-making, perseverance and responsibility, in short, to develop the own will of young people.

Passive observation of classroom instruction and verbal exchanges, which are reduced to class heads and teachers, can thus be seen as a process of acculturation, that is to say the introduction of too many elements in a given transmission system. The process operates at the individual level but can also extend to all or part of the group constituted by the class: those who do not (much) enter the exchange space established in relation to work school. In addition to the fact that they do not incorporate new meaningful data, those they possess are de facto devalued, as is the knowledge of a people colonised by another people claiming their superior knowledge, or those of the members of a village or neighborhood to whom one tries to impose a development project without (much) interest in their real concerns and needs. The group work can then attenuate this acculturating effect by reintroducing a contextual space where it is, sometimes cruelly, lacking; Human relationship, actually, produces contextual space. Why, then, should it be placed at the bottom of the hierarchy?

This kind of excess, to which all the young members of a society are subjected, is a true initiation into the adult world - a particular adult world, socio-culturally marked to be more precise. Turner (1991) has pointed out the characteristics (partially taken from Arnold Van Gennep) of the separation and isolation of the social world, and then aggregation into the adult world, a passage in which values are reversed because of the tests and in which the apprentices of the social order are considered on an equal footing (Turner et al., 2017). The students who accept these initiatory excesses are thus part of the selective process - induced by the force of social logics that go beyond individual will - of the new forms of elitism resulting from the adaptation to such a learning context. From this point of view, the moral obligation of schooling - socially much more important than the official obligation, because articulated to the putting into practice of active social values - recognises school as the major initiatory act of the societies forcing their children to go there.

Children learn there the common social relationship model (Rorty, 1989). They are also given the opportunity to prepare themselves to enter a specialised technical, scientific, literary or other field domain, thereby contributing to the creation, maintenance and perpetuation of separate social fields. 
This separation (Dumont, 1977; Durkheim et al., 1938) induces in turn the difficult communication of a domain (macro level: political, religious, economic ...) or a subdomain (micro level evoked above: family, neighborhood, work ...) to another. Specialisation by disciplines, on the other hand, induces the secondary effects noted above such as anonymity, rigidity of relationships and latent elitism. Early specialisation of subjects and separation of fields complicate the transmission of knowledge as if the processes of formalisation could hardly facilitate communication, dissemination and exchanges within a social where complementarity appears increasingly difficult to preserve.

In addition to the examples of Javanese ritual initiation that I take up in the next section, those of Indonesian secondary schools that I will comparatively present express these latent shifts. The variety of courses and the widespread absence of links between the subjects taught there produce some of the effects noted above: the importance of the theoretical content, the learning of the noncoherence of the subdomains as a norm ... Nevertheless, tendency to isolate the person, because of the undisputed dominance of the teacher, and the prohibition for students to communicate with one another, is frequently adapted and questioned in some institutions, as we shall see. Thus, while individuation remains the hallmark of institutions and systems that insist on learning content, the description of high schools in which relational circulation is valued, despite the emphasis on the national curriculum, suggests that social relationships can also be taken seriously into account in a formal context. The social relations developed there are not limited to a set of interpersonal relationships but are well integrated in a given space and in a given time - also valued and not considered as simple utilitarian supports -, constituting with them a true environment.

\section{Effective sharing of knowledge: neither theory nor practice}

In a context where social fields are clearly separated from one another, the notion of content and the related practices facilitate the way of these entities (contents) from one sector to another (scientific knowledge to school context or to other extended media, in particular, or their use for political, economic and more broadly ideological purposes). In fact, this very notion of learning content implies a very particular and ideologically marked perspective, in which prevails the problematic idea of autonomy. Indeed, the most advanced knowledge represents the culmination of a school of thought, a lineage of researchers. Autonomy - if any - exists only in the environments in which this knowledge is applied, transposed, rehabilitated, recovered, reused, deformed. It is therefore a matter of relative autonomy.

The main problem remains that the idea of autonomy has been imposed and that it is continuing its course in the meanderings of information centers (the media and the Internet in particular) - subjected to more or less ideological strong pressure, depending on the case - who peddle it without always taking into consideration the contingencies of contextualisation. The principal dissemination center of this idea - since it is establishing the norm in a massive way among the social subjects - is none other than the modern school. The concept of knowledge with a fixed, general and impersonal tendency is developed there, but without clearly explaining the reifying process of transposition (didactics) deriving from the source of scientific knowledge and linked to a genealogy of researchers (Maury \& Caillot, 2003).

In the background of these vernacular ideas of the content and related questions, lies the generative dichotomous partition "theory-practice", very discussed in the sociological field (Billeter, 1984; Bourdieu, 2018; Guille-Escuret, 2003; Sigaut, 2003). In particular, there is the over-valuation of knowledge in relation to know-how (Mauss, 1923; Sigaut, 2003), the devaluation of the practical dimension in relation to theory (Bourdieu, 2018). To summarise these aspects I have already discussed elsewhere (Grave, 2012), let us say that from the point of view of transmission, such a strict opposition does not make sense insofar as the incorporation of knowledge obeys rules similar to those of know-how. One of these rules - particularly 


\section{JPPM (Jurnal Pendidikan dan Pemberdayaan Masyarakat), 6 (2), 2019 - 152}

Jean-Marc de Grave, Puji Yanti Fauziah

pointed out by Bloch (1991) - is that the assimilation is gradually established before the automatisms confirm the definitive integration within the body schema. The school allows this type of integration, but more so, apparently, with regard to the assimilation of elements related to place, time and relations with others. Much more than with regard to the integration of knowledge whose content and logics are constantly changing.

As a result, I have been led to note (Grave, 2012) that in Western post-industrial societies the practice is still generally seen as the disinherited child of theory (Bourdieu, 2018; Sigaut, 2003; Singleton, 2004), it is rather different in Far-East regions where the reflection exists mainly in reference to the empirical action and to the context, which implies a particular relation to the social dimension and to the world.

Since the years 2000, during which fieldworks related to this collective book were carried out, upgrading of the vocational or technical sectors in the West, while the Far East countries are submitted to the virus of academic excellence, as indicated in the recent reports of Program for International Student Assessment (PISA) from the Organisation for Economic Co-operation and Development (OECD) and the in-situ observations we can make on education. Nevertheless, these ongoing processes do not prevent the use, in Asia, of relational codes and of specific conceptions on time and place (Ibid.). The loss of bodily reference and deferential signs - related to the devaluation of bodily practices - plays an undoubtedly significant role in the process of abstraction of the integrated ratio to temporality, to space and to others (Chicharro, 2012; Gibeault, 2012; Leucci, 2008). This relative consummate loss in the West seems to interfere there (Grave, 2012). Nevertheless, in my day-to-day fieldwork, it is clear that specific relational patterns persist that do not show marked opposition to "practical theory" and confirm the belonging to a community. In that respect, I would like to refer directly to the Javanese nyantri conception cited in the introduction as a comparative standard for better measuring the gap between knowledge and its social anchorage. According to this conception, what is put forward is the relational mode of the "student" (santri) insofar as he "acts as a student" (nyantri) with a master and within a community, exchanges taking place between the different members of this community much more than directly with the master. In this perspective, knowledge is that of the group concerned. We can even say that it is assimilated to this group (in parallel to a person who is representative of the group, like a master).

The community in question can be organised in a network (like the religious schools of the Hindu-Buddhist period and today Muslim schools) or not (concerning any type of artistic, artisanal or literary activity...). In connection with this type of social relationship, the idea is that all knowledge has meaning only if it is put into practice by the community in which it circulates. The conception of hoarded knowledge does not make sense or comparatively little - contrary to the patrimonialising conceptions very popular today - and this state of fact is reflected in the vocabulary itself as it reflects practices: nyantri ("to act as a student"), but also ngèlmu ("to act to know") which is always used in the active verb form in Javanese.

I have evoked at the beginning of the text the different contexts of learning on which I worked - governed by this relational and conceptual mode (de Grave, 2001, 2007, 2009, 2011, 2013, 2014a, 2014b; Grave, 2007, 2012) - to retain within the framework of this essay ritual initiation groups and highschools. As I have shown in a synthetic way, the comparative approach of different case studies has revealed conceptual and practical shifts in these two types of activities. Thus, dealing with ritual initiation, I have shown in great detail (de Grave, 2001, 2014b; Grave, 2007) how the students, to whom a whole cosmology and the ancestral cults are transmitted by a Javanese master, his assistants and their community of belonging, developed a relation to others, to space and to time. I have comparatively described this relationship in retrospect (Grave, 2012) as "integrated" insofar as it implies a consensus between concerned members. I was able to estimate this consensual aspect in contrast to the 
groups - of different religious, political or other denomination, which I enumerate in the first part of this text - that adapted Javanese initiation to their ideological contingencies. In one case, adaptation is integrated with the conceptions of Islam (de Grave, 2001, pp. 147-207; Grave, 2007): local cults, vernacular relationships to time and space are not taken into account. The relational mode is then strongly modified to the point that one approaches a conception in which the content plays proportionately a role more important than previously. Knowledge, although it is part of a claimed genealogy, is much more formalised and indifferently transmissible by such and such a person, even if the master and his assistants retain marked prerogatives.

These tendencies - a comparatively undifferentiated relationship to time, place, people and knowledge - are exacerbated in the other study case of a group influenced by the Indonesian State ideology, which developed the Javanese initiatory mode in sports and health practice (de Grave, 2001, pp. 209-287). We find here a form of content formalised to the extreme, to the point of reaching a degree of standardisation comparable to that which is generally elaborated in school environment. In the latter case, it may be said that the unifying characteristics which emanate from the nation-state, even if they do not assume a completely univocal form, overlap with Alain Pierrot's findings concerning policies of self-learning of the national language in France (2002) and elsewhere (2012a: 11), or (Gaudin, 2009) about the process of martial arts sportivisation in the world. It appears that the modern mode of non-Muslim schooling, which has been developing in the Indonesian population since the beginning of the twentieth century (Grave, 2012), sets a precedent: like the modern martial arts schools previously mentioned, its characteristics are taken up in the context of non-school activities (de Grave, 2009, 2011, 2013; Grave, 2012).

This aspect of advanced standardisation leads us to the school context, which represents not only the main competitor of the activities of ritual initiation in Indonesia, but also in a broader way - as seen in the previous section - the new initiatory mode adapted to the contingencies of modernity. I conducted ethnographic research in five Indonesian high schools in the same region of Java where I held my investigations of ritual initiation. I must say that these surveys have been greatly assisted by those of the previous apprenticeship modes, and have also illuminated somewhat obscure points concerning initiation.

I conducted ethnographic research in five Indonesian high schools in the same region of Java as my investigations of ritual initiation. I must say that these surveys have been greatly assisted by those which have dealt with the previous modes of apprenticeship and have also shed light on obscure points concerning initiation.

Two of these five high schools - a state one called $\mathrm{SMA}_{3}$ and a private catholic one called de Britto - use a tutorial mode of learning focusing on group work which, compared to other high schools, pushes students to develop at the same time the sense of responsibility, autonomy and sociability. Though evolving in a highly formalised environment, high school students appropriated the space and the temporality of the school. This method of group work matches with the pedagogical policy and plays a very important role in the learning process. Voluntary subjects and activities parallel to the national curriculum enable young people to feel involved and to learn to become responsible by themselves, thereby confirming, once again, the observation of (Dumazedier, 1988) that leisure activities (optional subjects, in this case) play a key role in the process of empowering young people.

This integrative nature of the relational mode runs counter to findings elsewhere in France where the school setting is presented in terms of constraint, especially in its temporal dimension (Audigier, 2007). It is from this observation and from my previous studies that I was able to clarify the notion of integrated relation of the relationship to time, space and others (Grave, 2012). Indeed, I developed an interpretation of relationships as being reduced in formalised learning contexts, but these two examples of integrative high schools show that even if the 
formalised tendency is marked in school cases, it is not univocal. On the other hand, given that these two high schools are the ones that obtain the best results from the city of Yogyakarta, the question arises as to where success lies: in the results of the ranking or in the socialising learning of the students? To clarify both the place of the informal dimension of relationships and learning within the school, I did a long-term survey centered on high school students as social people and not as pupils.

\section{Appropriation of School Space-time by High School Students}

Extensive fieldwork enquiries within the framework of a two-year research contract (September 2014-August 2016) have allowed me to understand the way high school students appropriate high school space-time out of class activities. My ethnography focused on students from Smapa high school in rural Pakem and Namche high school in downtown Yogyakarta. Both are state high schools and are located in the Yogyakarta Special Region. They were selected because of their similarity in size (6 to 800 students) and academic achievements (average). This ethnography reveals the strategies that students develop and the activities they preserve on their own to build themselves as social beings. It reveals how they are reappropriating educational aims ill-suited or inappropriate for their age group. These aspects are not taken into account by the ministerial authorities, but are more by the field actors, executives and teachers of schools, parents, school security, police and public of proximity.

The point of view of high school students also opens perspectives that students do not defend the interests of a specific value system. Their own system of references seems comparatively very open, even if their class of age submits them to the constraint of starting making choices. Ethnography thus questions the nature of the school. For example, is it too much future-oriented (Audigier, 2007)? Indeed, the data collected indicate that it implies a temporality in which the future invades the present, imposing on young people for whom the uncertainty of adult- hood (professional path difficult to choose, high competitiveness, unemployment, specters of corruption, nepotism, destruction of the environment ...) infers a relationship with time that does not suit their aspirations marked by existential idealism.

At the same time, this increasing inevitability of choices leads them to look beyond the formal discourse they are used to hear, and to develop a critical discourse that is often well-argued This discourse indicates a thorough knowledge of the ongoing processes of the secondary education system. and the superior, and sometimes the general mode of social functioning. It thus indicates the existence of a specific relationship mode that enables them to communicate the information considered important, such as those relating to the recruitment strategies of schools, universities, the world of work, or those relating to examinations and homework. This set of exchanges goes beyond the strict framework of information communicated to students. From the own point of view of the students we can even say that it encompasses them.

Indonesian high school students develop their own networks, their own logic of action, their own values, their own language and, consequently, their own activities. However, they rely heavily on existing structures known to adults and often approved or even created by adults, explicitly or tacitly. As a result, local values, strongly marked by regional social practices in which language here Javanese - and local modes of representation have a marked impact on practices. The Javanese socio-cultural heritage thus enables young people to organise all kinds of activities independently between people of the same age group. Through the interviews it appears clearly that these activities they develop by themselves are the ones they value the most. They give them the opportunity to build themselves because of the sense of mutual help they are brought to develop. But they also appreciate being pressured by their peers, forcing them to consider differences in personalities in situ and in the action.

At the same time, school activities are generally posited by them as important for the future, but the views on their usefulness 
JPPM (Jurnal Pendidikan dan Pemberdayaan Masyarakat), 6 (2), 2019 - 155

Jean-Marc de Grave, Puji Yanti Fauziah

are often shared; some see it as a utilitarian contribution while for others it is all relative, if not absent. Finally, the relation to other activities - family, friends, religious, optional classes or activities outside schools - also present different points of view.

Thus, what gives meaning to this action, to these different categories of activities, is the need to build together, to carry out a common task through an effort conducted in face-to-face groups. We find there two elements absent from the formative school mode focused on the person isolated in the action and subjected to a mainly intellectual learning and offset with respect to the physical presence action. These elements are not only absent, but they often come in opposition to the mode of inculcation of school knowledge inherited from the colonial period. These two tendencies sometimes present contradictory injunctions for students even for teachers and parents who would like to see their children succeed in school but also preserve their cultural identity - linked to the diffuse nature of the reference systems in question.

In the rural high school Smapa, there is a strong ritualisation of activities. This translates into speeches pronounced in Javanese with the wearing of traditional clothing, the frequent use of prayers (Muslim in this case). In this continuity, Javanese artistic (dance, theater and gamelan) and craft (batik, wood crafts) activities are available in optional (art) and compulsory (local crafts) classes, while they are not available in Namche. Students participate in exhibitions where they sell their own craft production. They often have a small economic activity developed in groups (such as the student cooperative, run independently) or in the family setting (resale of products made by parents). This trend is also linked to the fact that many of them will enter working life at the end of high school. In this regard, it is worth noting that teachers in Smapa-rural also have complementary income-generating activities (notably agriculture and product sales) which are absent in Namche. Outside school, Smapa's students who live in Pakem district are involved in youth official organisations in their village. They organise artistic activities, sports tournaments, intervillage games, community work, commemorations of important events, etc.

Urban Namche students do not usually have to intervene in youth organisations. The equivalent for them - because involving autonomy of action and intergenerational involvement - lies in the development of extracurricular community activities at the head of which comes the preparation of the Art Day which solicits the participation of half of the students of the Namche high school over a period of three months in relation with alumni of the school. At the same time, a relatively large portion of their time (6 to 12 hours a week) is devoted to after school support centers, where students come out exhausted in the evening and go straight to bed, which also limits the time spent with family. This limitation is also linked to much more numerous places in the city, such as cafes, shopping malls, and recreational areas where high school students like to go in groups. They also spend much less time on Javanese ceremonial and religious affairs. Some high school students are not involved in organisational religious activities which is impossible at Smapa.

In parallel with the rural village organisations and the urban Art Day, there are non-academic activities common to both high schools as the reception of new students, scouts and the intra-school organisation of students (Osis). These two last ones induce a marked intergenerational character and are considered very important on the formative and experiential plans. Indeed, their purpose is presented to forming leaders for the nation. All these community activities appreciated by high school students are opposed to those of individual work related to the class, by far the least valued in the words and answers to questionnaires of students, because of the solitary nature of the action involved.

\section{Differences Between Rural and Urban Settings}

This comparative overview shows that the orientations of the aims of the two high schools are relatively different. The school context is not exactly appropriate in the same way in each of the case studies. The activities 


\section{JPPM (Jurnal Pendidikan dan Pemberdayaan Masyarakat), 6 (2), 2019 - 156 \\ Jean-Marc de Grave, Puji Yanti Fauziah}

of the rural high school and the points of view expressed therein reflect a form of ideological stability and homogeneity anchored in a social and cultural context which does not, however, call into question the recognition of nation-state membership.

The fact that the majority of pupils do not go to higher education still confers on class activities a limited nature in time and in training objectives. The main properties of class work are then limited to accepting some form of discipline and authority rather than the need to acquire directly reusable content information in pursuit of life.

In parallel, the activities - class or not socioculturally marked or related to the locality are more meaningful with regard to the life plan of these young people who decide for the majority of them to enter an active life enrolled in local networks that they have already started to establish during high school or before.

For the urban high school, easier access to higher education gives a more concrete orientation to the class activities of the national program. Nevertheless, the curriculum followed in higher education (but also for high school) often does not correspond to a personal choice. Obstacles to such a choice begin with parental authority whose objectives often do not coincide with those of the pupils.

Then there is success in the assessments of the high school, and in the assessments at the entrance of the university to which the quotas allocated by each university to the various high schools and the numerus clausus specific to the different sectors are combined. Thus, based on all these criteria, the candidate performs all kinds of calculations that can push him to pass an entrance examination for a sector that does not interest him but for which he is likely to be admitted.

This relativity of choice and success generates anxiety among high school students who are struggling to establish a project of stable life and close to their aspirations. In addition to the less marked presence of local socio-cultural elements mentioned above, the greater diversity of personal choices in the urban context is accompanied by salient doubts that complicate the orientation of reference values for young high school students. To this is added the pressure coming from the ministry - of school heads who push students towards an action of excellence that remains abstract to them and thus favors intergenerational schism.

\section{High School Society and Educational Policies}

From this overview, the high school society appears in the complexity of its own rules. These include traditions that teachers and parents have known (class, scouts, national, regional or high school ceremonies, exams ...) and still contribute to perpetuating as for scouts and very popular groups of alumni. They also include new practices, some of which are endogenous: vocabulary, sms and social networks, introduction to violence in boys (down), girls' leadership (in development), self-photos, traveling by motorbike... And other exogenous: after school support centers, difficulties to enter university, declining interest in local ceremonial and cultural practices, marked formal development of religious organisations, exacerbation of academic competitiveness...

From these surveys, the central finding is that the friendship high school students build during three years is lasting sustainably - as indicated by the testimony of adult informants - because it is built on concrete joint projects facing the stressful class individualising practice. As such - and this is what the study of the rural school of Smapa and urban Namche confirms in comparison with my surveys of the 20oos (Grave, 2012) it appears that in high schools in which community activities cannot be developed autonomously, high school students can difficultly or cannot appropriate school space, with the consequence that the intergenerational bond of trust is poorly established. On the other hand, individual action and performance can be strengthened, which is in line with the ongoing state educational policy. This policy is not much taking into account long-term implications such as the gradual disappearance of existing practices and relational modes. 
The double case study thus reveals two tendencies within the common share of the high school institution. One is imposed from above by the ministerial authorities and aims to make young people conform to the logic of competitive individualism. The other is part of existing practices at the local level, in which personal action is more at the service of a given community. If individualism seems to progress, it is far from dominating in the examples studied. However, between the logic of the secular state and those of regional practices still very strong, stands the logic of formal religions called to standardise more and more in contact with secularism.

\section{CONCLUSION}

The starting point of this article is to explore a particular aspect of my research on transmission systems and the relationship between formal and non-formal elements of these systems, including the place of contents with regard to relational modes. In the course of the analysis developed, it appears that the circulation of contents depends on the marked separation of social domains and subdomains: they are transformed from one domain to another (from the scientific milieu to the media or the school environment, for example). In the perspective of (Dumont, 1977, 2015), who showed how economics took on attributes of politics and religion, we could say that the contents carry with them attributes - generally valued, like scientific knowledge, which justifies their attractiveness from their original context. A competition of domains is thus developed, which aims to enhance the radiance of contents reflecting knowledge some of which dominate, others not, others are ignored or unrecognised and still others disappear. The jerky transformation that takes place when moving from one domain to another is concomitant with the saccades that characterise the transition from one relational context to another - from the family setting to the school setting, for example.

If one considers the restricted relations of a partial context, it appears to be very difficult to produce qualitative reports that are not limited by space (limited access to only one type of activity: work, leisure, study
...) or by time (limited time to develop a given activity). The analysis shows that the more learning contents are put forward the less contextual activities are taken into account unless these contents benefit of significative relational system recreated and dedicated to them ( $\mathrm{SMA}_{3}$ and de Britto high schools). If not, the relational system becomes limited and carries side effects (rigidity of relationships, reconstructed elitism, increasing abstraction of knowledge).

Notwithstanding these specific cases, the global imposition of contents proposed as universal by the State present the characteristics of an initiatory activity to which all members of the community must submit. In this perspective, the over-emphasis of learning content appears to be ideologically marked by the social contexts in which the advanced division of domains is practiced and is characterised by a certain form of autonomy of the content itself. Thus, the Javanese and Indonesian-Javanese transmission systems of ritual initiation that I have studied reveal the transposition of a local knowledge to the basis inseparable from the Javanese mode of social relations inscribed in a proper time and space converging with or opposed to a Muslim value system and a nationalist Indonesian value system. This transposition results in the development of similar standardised learning content - in terms of their empowerment in relation to a given social anchoring - to those that are circulating within the school environment. Moreover, it appears, as we have seen, that this process, characteristic of the school context, spread on many local activities, including those of initiation with which the modern school competes to become the new mode of initiation for Indonesian youth.

Finally, the description of Indonesian high schools presents modes of transmission that do not overvalue the learning content to the detriment of relationship established between the different members of some of these high schools. The two first high schools I have described ( $\mathrm{SMA}_{3}$ and de Britto), present in their internal operating mode of transmission the same configuration as the nyantri system found in traditional kanuragan insofar as it shows how it is very 
JPPM (Jurnal Pendidikan dan Pemberdayaan Masyarakat), 6 (2), 2019 - 158

Jean-Marc de Grave, Puji Yanti Fauziah

difficult, if not impossible, to separate a socalled learning content from a learning community and a social environment. From these two examples we can understand that socialising ability is all the same educable and transmissible in a high formal context, and that the positive integration of the relation to time, space and others clearly adds that of the relation to knowledge.

In this perspective, the two other high schools (Smapa and Namche) also present a marked aspect of socialisation of relationship and knowledge, but rather oriented towards external local institutions of the school and of the students. In the two first cases, socialising aptitudes are more inherent and focused to the school, in the two second cases socialising aptitudes developed in the school are echoing (and adapted to) those existing in the surrounded community, though in different ways appropriate to rural or urban contexts.

The study of all these learning systems thus reveals different scenarios:

- a system anchored in a rather homogeneous socio-cultural context in terms of its relationship to time, space, others and knowledge (the Javanese ritual initiation);

- a form of system integrated into a universalist ideology in which time, space and social relationships are shifted or separated from other types of social activity (schools of ritual initiation transposed into Muslim or nationalist contexts, becoming schools of martial arts);

- a modern school-type system that positively integrates relationships to time, space, others and knowledge, but rather endogenously to the school context (the first two high schools presented, knowing that in parallel to this model, there are also schools where relationships to time, space, others and knowledge are presented in terms of relative constraints).

- A system similar to the previous one but where endogenous activities are much more closely linked to the social context and local institutions (the two following high schools).
- The social struggle for content: content/ derivative content models, integrated content/content integrating

This draft classification therefore proposes to measure social integration on the basis of these four criteria of time, space, others and knowledge to speak of an integrated or non-integrated relationship to different degrees. Concerning the value of knowledge and learning content as an important aspect of social integration (and, in its extension, of the understanding of the value system of the society or group concerned), it is important to stress here the value of the ultimate lessons of initiation.

It seems, indeed, that the habit with which we consider school makes us lose sight of the essential role it plays in the process of integrating ultimate practical values by children and young people, that is, practices oriented towards an ideology whose ethical aspect is the subject of consensus. It is certain, as Pierre Bourdieu describes it through his work, that utilitarian aims combined with class interest logics play a central role in the routinisation of the school and the loss of sight of a practical consensus (Bourdieu, 2018).

But it also appears, in a noncontradictory way, that the initiatory aspect of the school is accompanied by a form of explicit non-recognition of its own initiatory dimension, which seems self-evident, like relational exchange and modes of learning. What is apparent in the processes described - whether they are school-based or ritual initiation processes - is that content can gradually be replaced by other practices and other content that are different and even of a different nature (cosmological conception/nationalist conception/utilitarian conception...). This alternation thus contributes to the accession of emerging classes and the renewal of the elites, so much so that we can talk about a form of content competition and ask ourselves the question of the extent to which this competition influences the trends of a given social organisation.

If we look finally at the ethical aspect related to this idea, it appears that the way in which content is considered as being autonomous from a social anchorage (what is 
JPPM (Jurnal Pendidikan dan Pemberdayaan Masyarakat), 6 (2), 2019 - 159

Jean-Marc de Grave, Puji Yanti Fauziah

called, for example, ideological, political or religious content), it is clear that the introduction of inappropriate "content" into a community - endogenous introduction to a given nation or exogenous - can potentially be dangerous; however, the competition of content discussed above leads to a significant increase in this type of penetration.

On this subject, can we speak of a form of hegemony that is established through the dissemination of content: writing, compulsory subjects, overvalued subjects, religious, scientific or secular books, information, ideological doctrines? Or a competition of content that goes beyond the social order itself? What seems certain is that the relative free will of social members is conditioned by content, that this content has a very relative ethical orientation in absolute value when it is caught in an encompassing competitive spiral, that this same content, finally, is led to serve as a support for social classes and emerging social domains.

\section{REFERENCES}

Audigier, F. (2007). Temps subi, temps construit. In Questions de temporalité. Les méthodes de recherche en didactiques (2) (pp. 15-27). Presses Universitaires du Septentrion.

Billeter, J.-F. (1984). Pensée occidentale et pensée chinoise: le regard et l'acte. In Différances, valeurs, hiérarchie (pp. 2551). Ecole des Haut Etudes en Sciences Sociales Paris, France.

Bloch, M. (1991). Language, anthropology and cognitive science. Man, New Series, 26(2), 183-198.

Bourdieu, P. (2018). Esquisse d'une théorie de la pratique. Précédé de trois études d'ethnologie kabyle. Le Seuil.

Chicharro, G. (2012). De la gymnastique à l'art graphique. Apprentissage et enseignement dans les écoles élémentaires chinoises. In J.-M. de Grave (Ed.), Dimension formelle et non formelle de l'éducation en Asie orientale. Socialisation et rapport au contenu d'apprentissage (pp. 157-177).

De Coppet, D. (1992). Comparison, a universal for anthropology (Vol. 1). Psychology
Press.

de Grave, J.-M. (2001). Initiation rituelle et arts martiaux: Trois écoles de kanuragan javanais (Vol. 33). Editions L'Harmattan.

de Grave, J.-M. (2007). Quand ressentir c'est toucher. Techniques javanaises d'apprentissage sensoriel (Issue 49). Association Terrain.

de Grave, J.-M. (2009). Genèse du pencak silat moderne: Note de recherche sur la standardisation des arts martiaux indonésiens sous l'occupation japonaise et à l'époque de l'indépendance (1942-1965). Actes de La Recherche En Sciences Sociales, 179(4), 112-117.

de Grave, J.-M. (2011). The training of perception in Javanese martial arts. In Martial arts as embodied knowledge: Asian traditions in a transnational world (pp. 123-143). SUNY Press.

de Grave, J.-M. (2013). Sportivisation des arts martiaux et contexte sociopolitique. Le cas du pencak silat en Indonésie. Staps, $100(2)$,

https://doi.org/10.3917/sta.100.0015

de Grave, J.-M. (2014a). Javanese Kanuragan ritual initiation: A means to socialize by acquiring invulnerability, authority, and spiritual improvement. Social Analysis, $\quad 58(1)$. https://doi.org/10.3167/sa.2014.580103

de Grave, J.-M. (2014b). Quel est le contenant des savoirs? Réflexions d'après les modes d'apprentissage javanais. Moussons, 23, 55-79. https://doi.org/10.400o/moussons.284 3

Dumazedier, J. (1988). Révolution culturelle du temps libre 1968-1988. Librairie des Méridiens Klincksieck et Cie.

Dumont, L. (1977). Homo aequalis. Genèse et épanouissement de l'idéologie économique. NRF-Gallimard, Bibliothèque des Sciences Humaines.

Dumont, L. (2015). Essais sur l'individualisme. Une perspective anthropologique sur l'idéologie moderne. Le seuil. 


\section{JPPM (Jurnal Pendidikan dan Pemberdayaan Masyarakat), 6 (2), 2019 - 160 Jean-Marc de Grave, Puji Yanti Fauziah}

Durkheim, É. (1980). Éducation et sociologie, чe éd. Presses universitaires de France.

Durkheim, É., Halbwachs, M., \& Dubet, F. (1938). L'évolution pédagogique en France. F. Alcan.

Gaudin, B. (2009). La codification des pratiques martiales. Actes de La Recherche En Sciences Sociales, 179(4), 4-31.

Gibeault, D. (2012). Réception pour un cadavre. Transmission et extériorité en Chine. In J.-M. de Grave (Ed.), Dimension formelle et non formelle de l'éducation en Asie orientale. Socialisation et rapport au contenu d'apprentissage (pp. 79-104). Presses Universitaires de Provence.

Goody, J. (2007). L'oralité et l'écriture. Communication $\mathcal{E}$ Langages, 154(1), 310.

Goody, J., \& Paulme, D. (1994). Entre l'oralité et l'écriture. Presses universitaires de France.

Grave, J.-M. de. (2007). L'initiation rituelle javanaise et ses modes de transmission. Techniques \& Culture, 48-49, 85-124. https://doi.org/10.400o/tc.3032

Grave, J.-M. de. (2012). Méthodes de soin actives et préventives. Apports des maîtres rituels javanais et rapport au développement. Moussons, 20, 33-56. https://doi.org/10.40oo/moussons.1585

Guille-Escuret, G. (2003). Efficacité technique, efficacité sociale. Le technique est-il dans le social ou face à lui? Techniques \& Culture, 40. https://doi.org/10.400o/tc.1414

Leucci, T. (2008). L'apprentissage de la danse en inde du sud et ses transformations au xxème siècle: Le cas des devadasi, rajadasi et nattuvanar. Rivista Di Studi Sudasiatici: RiSS, 3, 49.

Maury, S., \& Caillot, M. (2003). Quand les didactiques rencontrent le rapport au savoir. Rapport $\mathrm{Au}$ Savoir et Didactiques, 13-32.

Mauss, M. (1923). Essai sur le don forme et raison de l'échange dans les sociétés archaïques. L'Année Sociologique (1896/1897-1924/1925), 1, 30-186.

Pierrot, A. (2012). Le silence des aînés. In Dimension formelle et non formelle de l'éducation en Asie orientale. Socialisation et rapport au contenu d'apprentissage (pp. 7-25).

Rorty, R. (1989). Education without dogma: Truth, freedom, \& our universities. Dissent, 36, 198-204.

Sigaut, F. (2003). La formule de Mauss. Techniques \& Culture, 40. https://doi.org/10.400o/tc.1538

Singleton, M. (2004). Critique de l'ethnocentrisme: du missionnaire anthropophage à l'anthropologue postdéveloppementiste. Parangon.

Turner, V., Abrahams, R. D., \& Harris, A. (2017). The ritual process: Structure and anti-structure. Routledge. 